\title{
Investigating the Effect of Storytelling in The Prevention of Re-Infection with Intestinal Parasites in Students of Primary Schools in The Villages of Urmia
}

\begin{abstract}
Background and Objective: Intestinal parasitic infections (IPI) with many complications cause stunted growth in children. Therefore, the present study was conducted to determine the effect of storytelling in the prevention of parasitic-intestinal re-infection in primary school students in villages of Urmia.

Materials and Methods: The present study is a quasi-experimental study that was performed on 400 primary school students in rural areas of Urmia in 2012. After performing fecal testing of all students and determining the needs of educational intervention, about the prevention of parasitic-intestinal re-infection was taught to the experimental group using storytelling method. Data were collected in two stages before and 6 months after the end of the educational intervention by a questionnaire using SPSS software, version 16 and Chi-square test was used to analyze the data.

Results: The findings showed a significant reduction in re-infection with parasiticintestinal infections in the experimental group compared to the control group after educational intervention through storytelling. Also, the level of knowledge of the experimental group increased after the educational intervention compared to the control group. Chi-square test with $p<0.025$ showed that there is a significant relationship between educational intervention through storytelling and reduction of IPI in students.

Conclusion: Storytelling method is effective in reducing the risk of re-infection of IPI among students. Therefore, storytelling for students in the field of prevention against IPI is recommended.

Keywords: Prevention; intestinal Parasitic Infection; Storytelling; Students Paper Type: Research Article.
\end{abstract}

Citation (Vancouver): Rezapour B, Khashaveh Sh. Investigating the Effect of Storytelling in The Prevention of Re-Infection with Intestinal Parasites in Students of Primary Schools in The Villages of Urmia. Iran J Health Educ Health Promot. Spring 2021;9(1): 56-67. [Persian]

Citation (APA): Rezapour B., Khashaveh Sh. Investigating the Effect of Storytelling in The Prevention of Re-Infection with Intestinal Parasites in Students of Primary Schools in The Villages of Urmia. Iranian Journal of Health Education \& Health Promotion., 9(1), 56-67. [Persian]

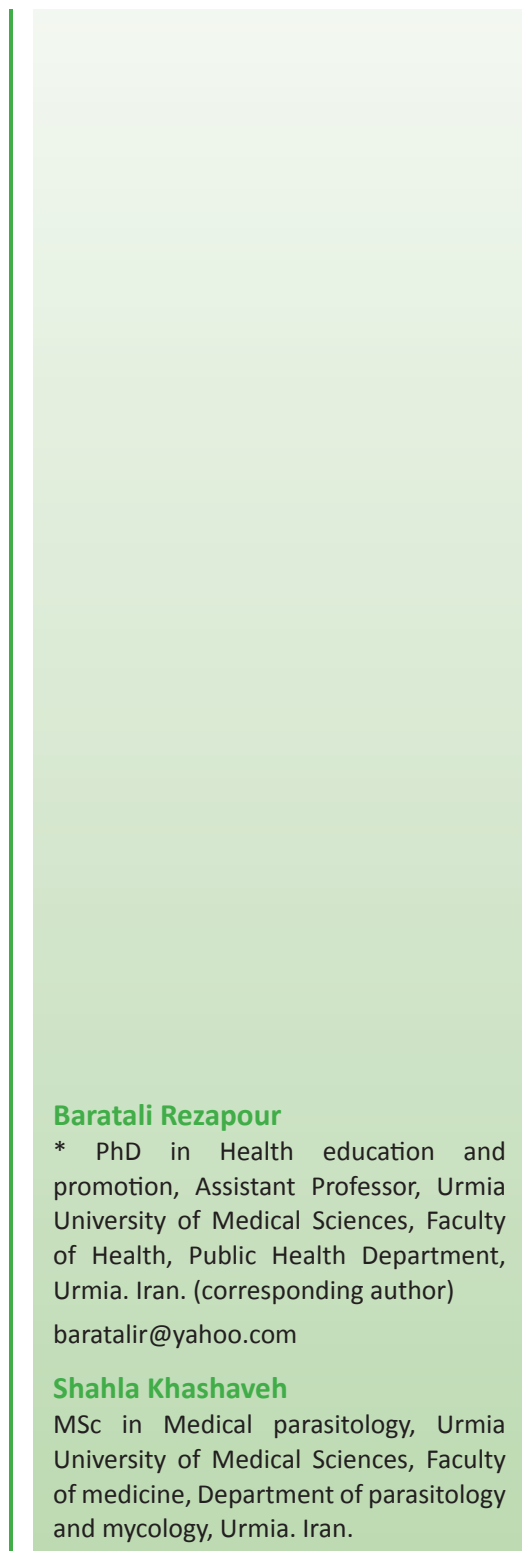

Received: 2020/05/21

Accepted: 2021/01/09

Doi: $10.52547 /$ ijhehp.9.1.56 


\section{بروسى تأثير قصه كويى در بيشغيرى از عفونت مجدد انكلىى - روده اثى در دانش آموزان مدارس ابتدايى روستاهاى اروميه}

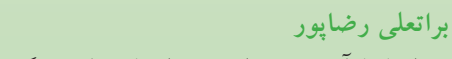

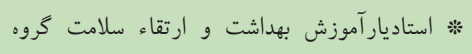

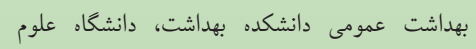

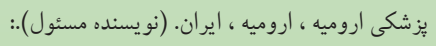
baratalir@yahoo.com

شها خشاو

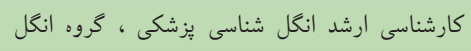

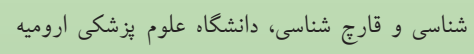

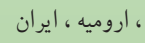

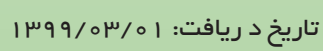

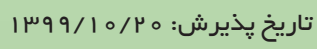

\section{بك بـ}

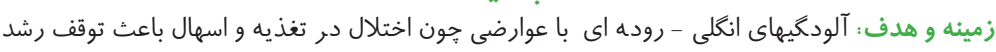

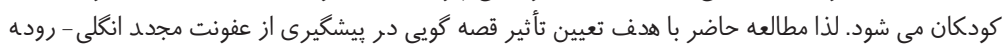

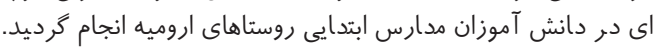

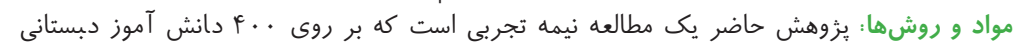

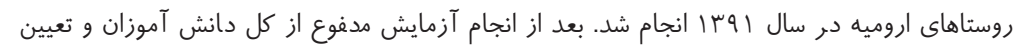

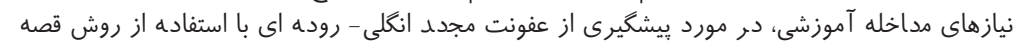

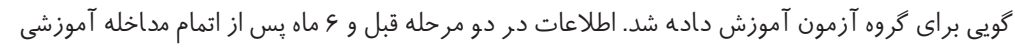

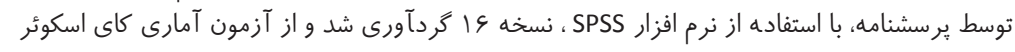

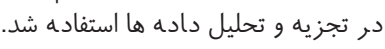

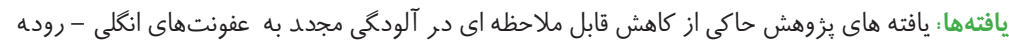

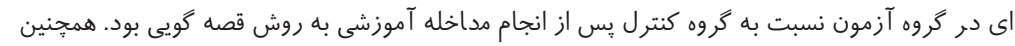

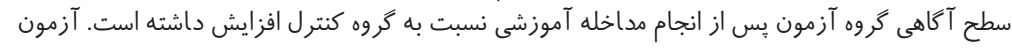

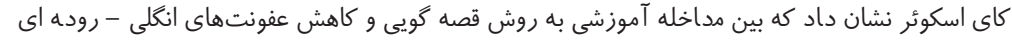

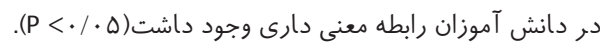

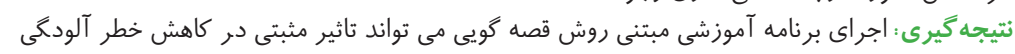

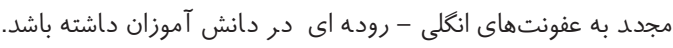

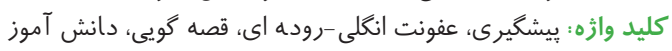
نوع مقاله : مطالعه يُوهشى.

> استناد (ونكوور): رضايور ب، خشاوه ش. بررسى تأثير قصه گويى در بيشگيرى از عفونت مجدد

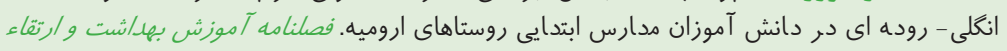

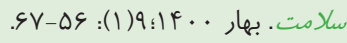

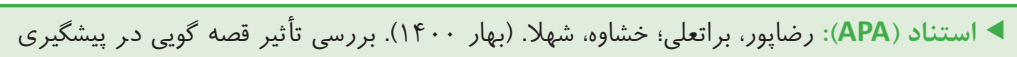

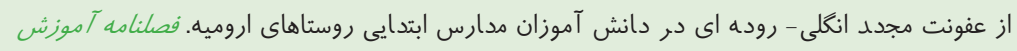

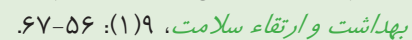


( • (1). كودكان و نوجوانان نسبت به ساير كروههاى سنى آسيب يذيرتر هستند و نسبت به اثرات عفونتهاى انكلى -رووده ایى از جمله سو جذب، كاهش وزن، توقف رشد، اسهال و كم خونى آسيب

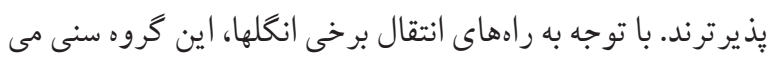

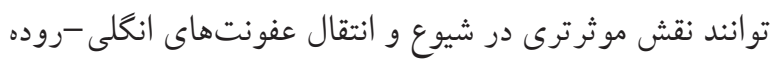

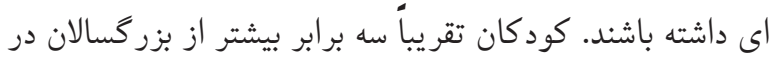

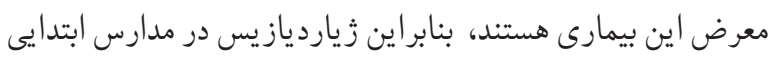

$$
\text { و برورشعاه ها بيشتر ديده مى شود (11). }
$$

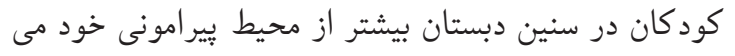

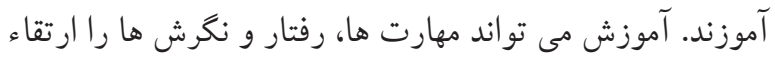

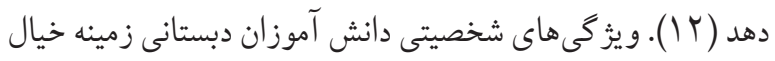

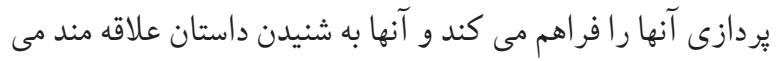
كند و نسبت به اظهارنظر و تجزيه و تحليل شخصيت ها و عملكرد

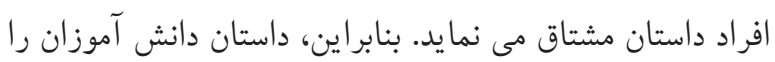

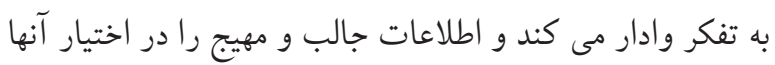

قرار مى دهد (سا) (1).

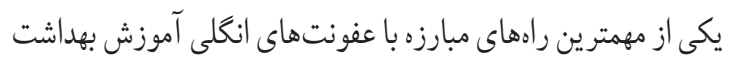

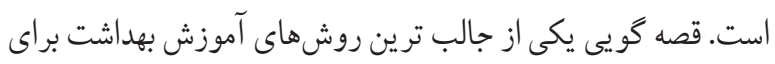

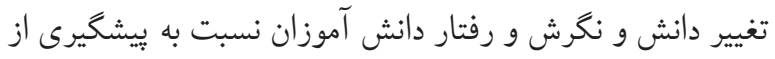

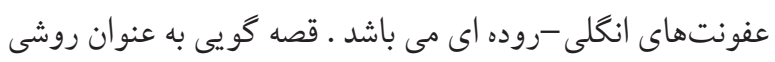

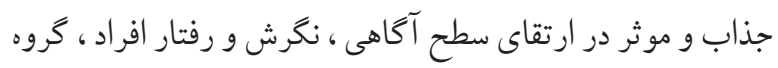

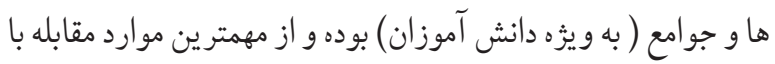
عوارض ، مشكلات و هز ينههاى عفونتهاى انكلى -روده اى به شمار مى رود. هدف از اين مطالعه تعيين تأثير مداخلات آموزشى با استفاده

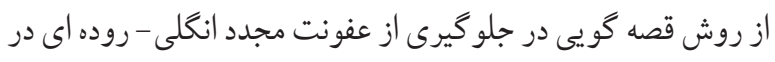
دانش آموزان دبستانى در مناطق روستايى اروميه بود.

مو اد و روش ها اين بثوهش يك مطالعه نيمه تجربى با گروه كنترل است كه بر روى روس

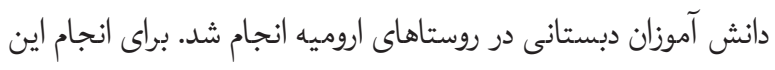

عفونتهاى انگلى از جمله علل مهم مرگ و ميرهايى هستند كه در

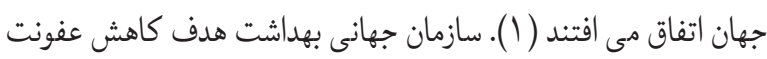

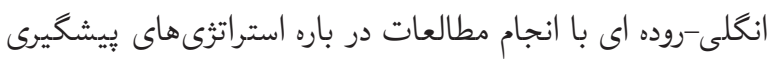

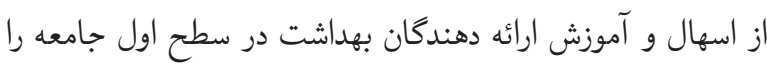
توصيه مى كند (Y). عفونتهاى انغلى -روده اى در كشورهاى در حال توسعه شيوع

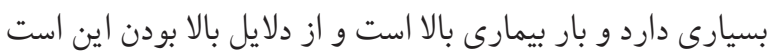
كه امكانات كافى براى تأمين آب آشاميدنى سالم ندارند (ץ).

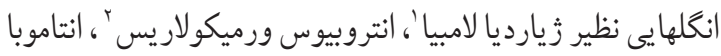
كلى" ، از جمله مهمترين عوامل ايجاد كننده آلودگى در بيماران

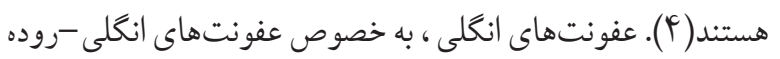

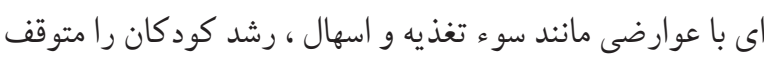

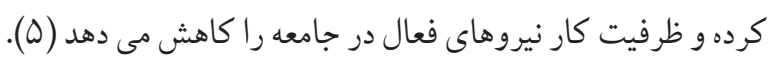

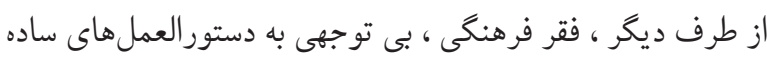

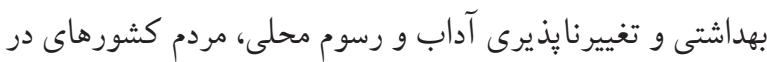

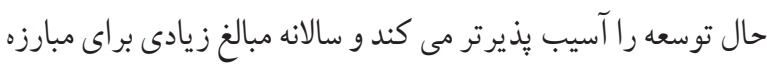

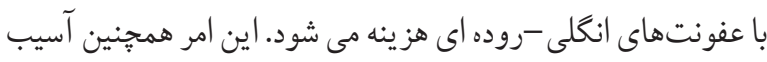

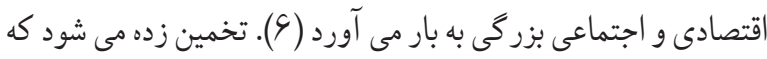

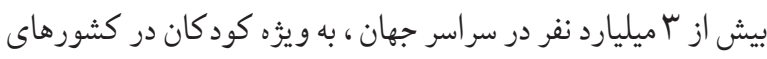

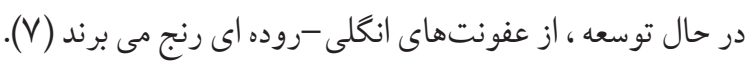

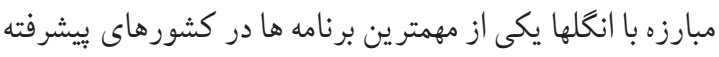

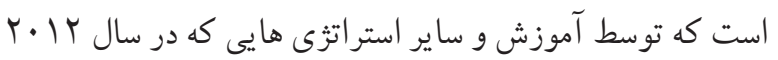

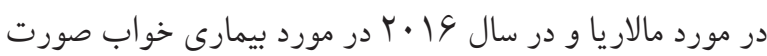

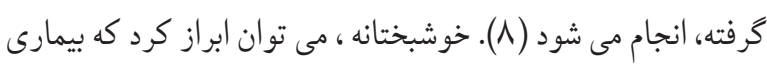

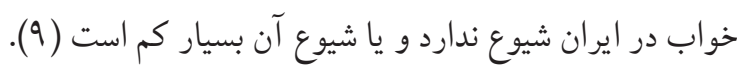

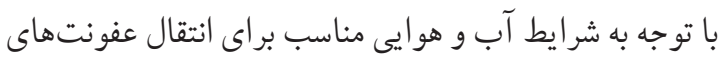

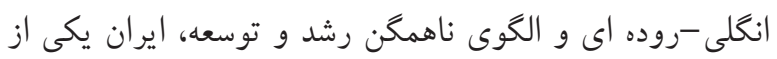

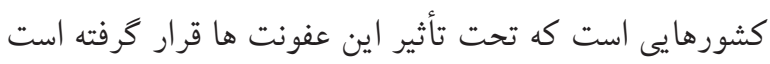

1. Giardia lamblia

2. Entrobius Vermicularis

3. Entamoeba coli 
دانش آموزان آلوده مدارس اين محال بصورت تصادفى سيستماتيك

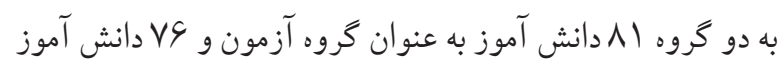
بعنوان كروه كنترل تقسيم شدند.

در همين زمان نيز مصاحبه اوليه و تكميل يرسشنامه قبل از آموزش و آزمايش به منظور كسب اطلاعات دمو كر افيك و تشخيص ريص

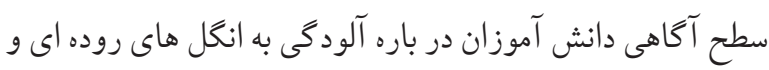
رعايت بهداشت فردى انجام شد.

سيس با هماهنگى مد يران مدرسه توسط همكاران هيئت علمى مجرى طرح، گروه آزمون بر مبناى روش آموزشى قصه گويى، تحت آموزش بهداشت فردى و محيط قرار گرفت(جدول ا ). و ماه بعد از كليه دانش آموزان كروه آزمون و كنترل دو نمونه مدفوع به طور مستقيم و به روش تغليظ فرمالين - اتر و دو نمونه آزمايش نوار جسب اسكاج گرفته شد و توسط ميكروسكوب نورى با لنزهاى •ا و · مورد بررسى قرار كرفت ـ در اين مرحله هم تمام دانش آموزان آلوده به مر اكز بهداشتى و يا يزشك معرفى شدند تا اينكه تحت درمان قرار كيرند. ابزار جمع آورى اطلاعات در اين مطالعه يرسشنامه محقق ساخته كه داراى سه بخش به شرح ذيل مى باشد. بخش اول شامل سن ، جنس، يايه تحصيلى، تعداد فرزندان خانواده بود. نتايج آزمايشاتى كه براى تعيين نوع انگل دانش آموزان انجام گرفته بود و از آزمايشگاه به محقق اعلام گرديد، در بخش دوم يرسشنامه نوع انكل ثبت گرديد. بخش سوم شامل سوالاتى در مورد راههاى انتقال و راههاى يّيشيرى از انتقال عفونتهاى انگلى روده اى بود. سو الات در مورد نحوه تهيه آب آشاميدنى، موارد استفاده از فضولات حاه توالت منزل، محل قرار دادن صابون در خانه، زمانهاى شستشوى دستها، مصرف سبزى همراه با غذا، كاشت سبزى خوردن در محوطه منزل، دادن فضولات انسانى به عنوان كود به مزرعه سبزيجات، عادت به مكيدن انخشت، عادت به جو يدن ناخن، رفتارهاى غير بهداشتى، محلهاى بازى غير بهداشتى، ميكروب و انگل جيست؟ جه ضررهايى دارند؟ علايم بيمارى انكلى، عوارض بيماريهاى انگلى، اقدامات يِيشخيرى از سرايت ميكروب و انگل، راههاى انتقال از طريق آب، خاك،
مطالعه، با توجه به اينكه شهرستان اروميه داراى f| دهستان است. از بين دهستانهاى شهرستان اروميه با روش نمونه گيرى خوشه اى يك دهستان (باراندوزجاى) انتخاب شد. از روستاهاى اين دهستان بصورت خوشه اى "ا مدرسه انتخاب گرديدند و كليه دانش آموزان مدارس انتخاب شده در دو جنس دختر و پِر جهت ورود به مطالعه انتخاب شدند. سيس جهت بر گزارى جلسه توجيهى، هماهنكى هاى لازم با مديران مدارس براى دعوت والدين دانش آموزان به مدارس به عمل آمد. ابتدا ضمن تشريح اهداف و ماهيت يُّوهش، در خصوص

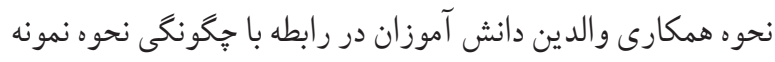
كيرى به روش جـسب اسكاج و جمع آورى نمونه مدفوع طى دو نوبت از فرزندشان، آموزش هاى لازم داده شد. سيس آزمايش مدفوع و جُبب اسكاج در دو نوبت به صورت متوالى در يك هفته از دانش آموزان گرفته شد و با استفاده از روشهاى فرمالين - اتر و مستقيم در آزمايشگاه انگل شناسى دانشكده يزشكى مورد بررسى قرار كرفتند. نتايج نشان داد كه DV دانش آموز به عفونتهاى انخلى _روده اي آلوده بودند و سFب نفر عفونت انكلى -رودهد اي نداشتند. در اين مرحله تمام دانش آموزان آلوده به مراكز بهداشتى و يا يزشك معرفى مى شدند تا اينكه تحت درمان قرار كيرند.

حجم نمونه با توجه به مطالعه توحيدى و همكاران(I I ) كه نسبت ابتلاى مجدد به آلودگى انگلمى در گروه آزمون هادرصد و برو در گروه كنترل VD درصد مى باشد با اطمينان هو درصد و توان • م درصد با احتساب • † درصد ريزش در اجرا تعداد نمونه براى هر گروه · نفر بر آورد گرديد.

$$
n=\frac{\left(Z_{1}-\frac{\alpha}{\tau}+Z_{1}-\beta\right)^{\gamma}\left[P_{1}\left(1-P_{\imath}\right)+P_{\gamma}\left(1-P_{\tau}\right)\right]}{\left(P_{1}-P_{\gamma}\right)^{\tau}}
$$

معيارهاى ورود به مطالعه، در موقع انجام مطالعه دانش آموز بايد از مدارس انتخاب شده باشد و تمايل به شركت در يثوهش داشته باشد. عدم تمايل به ادامه همكارى در بيزوهش و نيز انتقال به مدرسه ديگر و يا ترى تحصيل نيز به عنوان معيارخروج از مطالعه در نظر گرفته شد. 


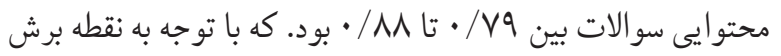

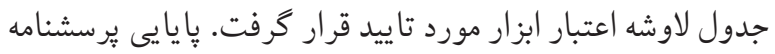

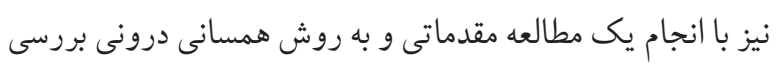
شد كه مقدار آلفاى كرونباخ براى سوالات AF/ • بر آورد كرديد.

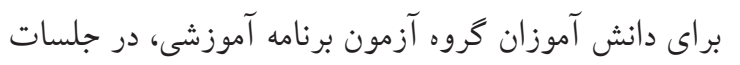

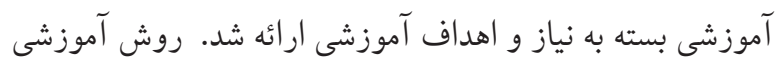

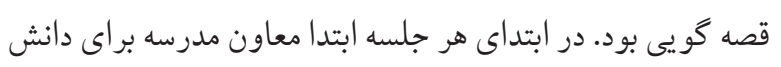

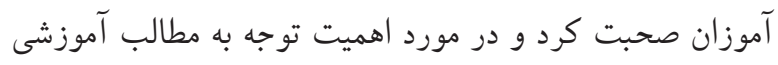

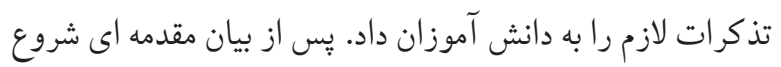

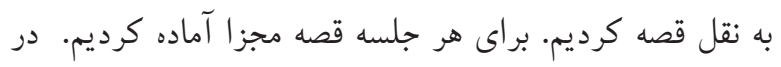
جريان نقل قصه از حركات دست و تغيير تن صدا استفاده شد و از

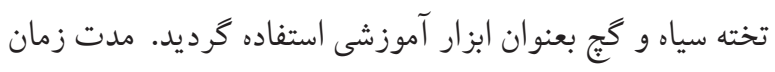
تخصيص داده شده به بيان قصه f أ جلسه يك ساعته بود كه البته أنه

ها دقيقه آن به بيان مقدمات اختصاص يافت (جدول شمارها ).
كوشت، سبز يجات، تماس بوستى، رعايت بهداشت فردى قبل از غذا و بعد از رفتن به دستشويى بود.

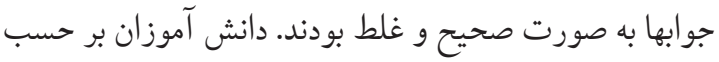

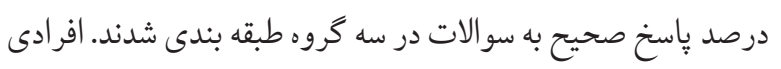

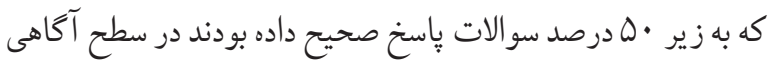

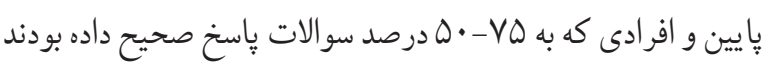

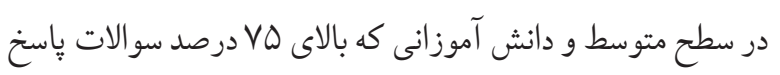
صحيح داده بودند در سطح آكاهى بالا طبقه بندى شدند.

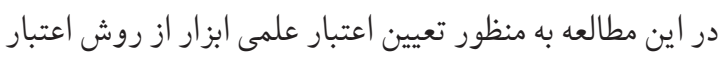

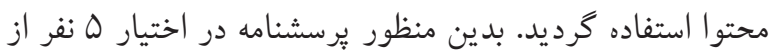
همكاران هيئت علمى متخصص آموزش بهداشت و ارتقاى سلامت

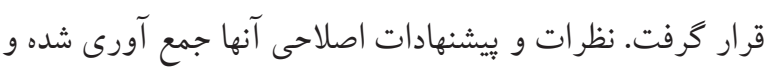

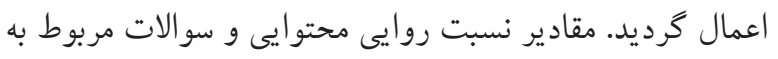

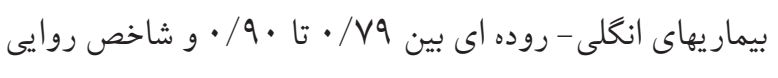
جدول ا. خلاصه فعاليتهاى آموزشى براى دانش آموزان ابتدايى كَروه آزمون در مورد آلودَّيهاى انغلى - روده اى

\begin{tabular}{|c|c|c|c|c|c|}
\hline (دقيقه) & ياد تجيرى & محتواى آموزشى & وسايل كمك آموزشى & نحوه اجرا & جلسات \\
\hline ro & يمفلت & 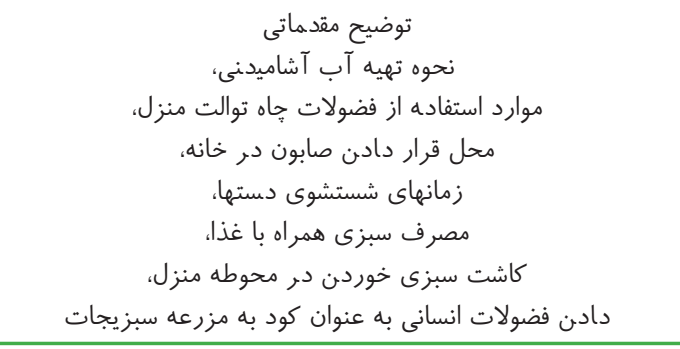 & كج و تخته سياه & قضه گويى انى & اول \\
\hline 10 & يمفلت & 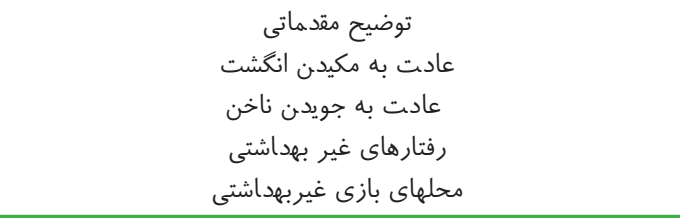 & كُ و تخته سياه & قضه گويى انى & دوم \\
\hline 10 & يمفلت & 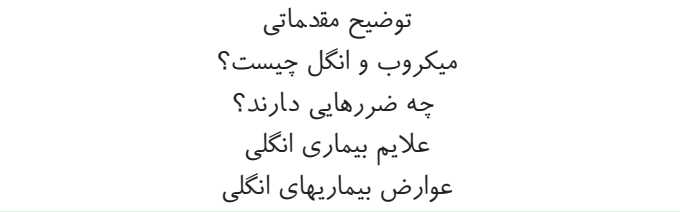 & كج و تخته سياه & قضه گونى سنى & سوم \\
\hline is & يمفلت & 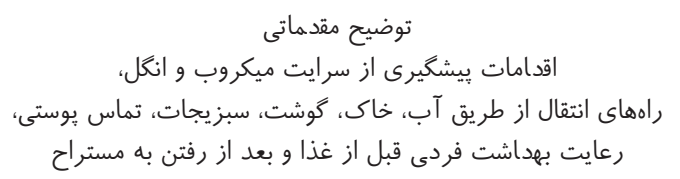 & كج و تخته سياه & قصه گويى سخى & جهارم \\
\hline
\end{tabular}


در پايان هر جلسه آموزشى، قصه همان جلسه بصورت يمفلت به در جمع آورى و تحليل اطلاعات بود.

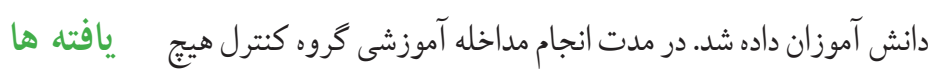

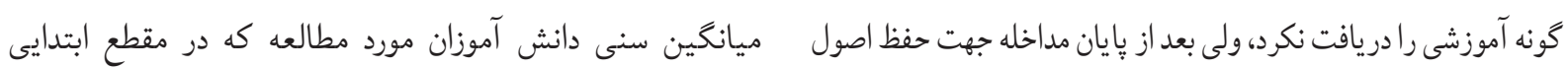

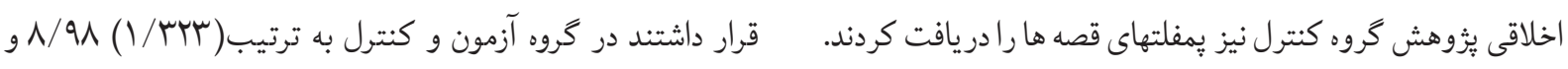

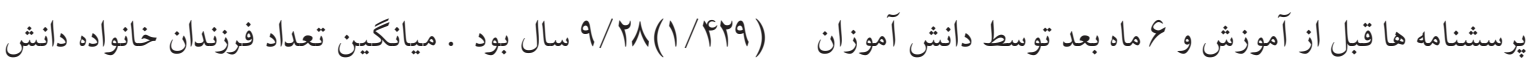

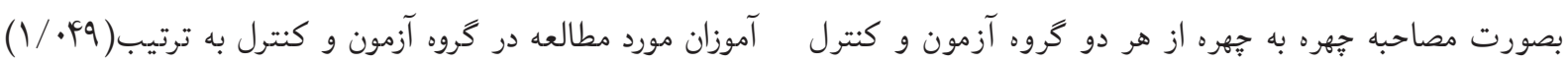

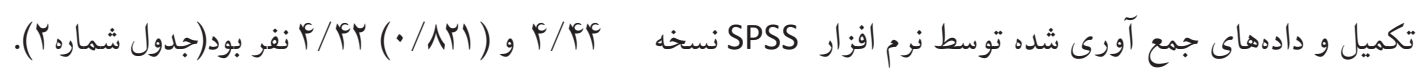

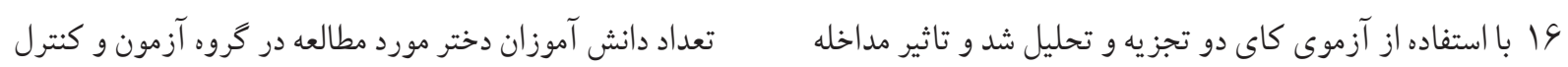

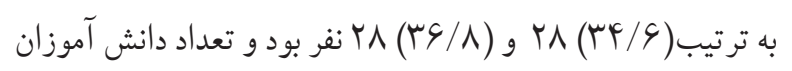

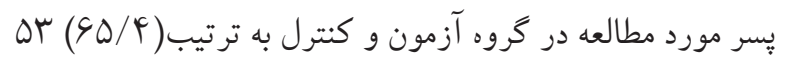

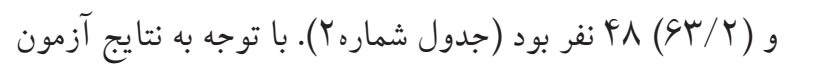

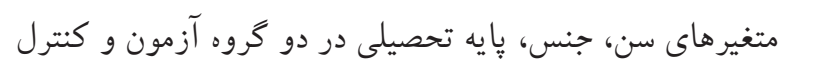

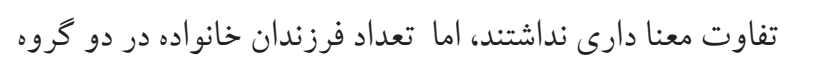

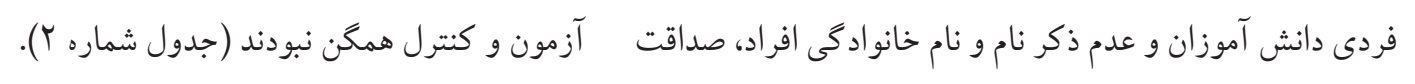
جدول r. توزيع متغيرهاى جمعيت شناختى در دو كَروه آزمون و كنترل

\begin{tabular}{|c|c|c|c|c|c|c|}
\hline \multirow{2}{*}{ نتيجه آزمون } & \multicolumn{2}{|c|}{ كروه كنترل } & \multicolumn{2}{|c|}{ كروه آزمون } & & \multirow{2}{*}{ 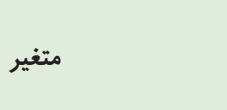 } \\
\hline & درصد & تعداد & درصد & تعداد & & \\
\hline \multirow{6}{*}{$\cdot / \Delta \mu \cdot=\mathrm{P}-$ value } & $10 / 1$ & ir & $19 /$. & ir & $\checkmark$ & \multirow{6}{*}{ سن } \\
\hline & $1 \pi / r$ & 1. & $r r / r$ & 11 & $\wedge$ & \\
\hline & $r \Delta / \cdot$ & 19 & $r F / V$ & $r \cdot$ & 9 & \\
\hline & $r \mu / V$ & 11 & $r F / V$ & $r$. & 1. & \\
\hline & $11 / F$ & If & $9 / 9$ & $\wedge$ & 11 & \\
\hline & $r / 9$ & r & $r / \Delta$ & r & Ir & \\
\hline \multirow{2}{*}{ - /VsG=P-value } & rs/A & rᄉ & $r F / s$ & rᄉ & دختر & \multirow[b]{2}{*}{ جنس } \\
\hline & $s \mu / r$ & is & $s \Delta / F$ & $\Delta r$ & يسر & \\
\hline \multirow{4}{*}{$\cdot /{ }^{*} V^{F}=\mathrm{P}$-value } & $r r / F$ & IV & $r \Delta / q$ & rl & 1 & \multirow{4}{*}{ پايه تحصيلى } \\
\hline & $1 \pi / r$ & 1. & $r \mathrm{r} / \cdot$ & IV & r & \\
\hline & $r \cdot / \Lambda$ & r & $r F / s$ & ru & r & \\
\hline & $r \mu / \Lambda$ & 11 & $1 N / 0$ & 10 & r & \\
\hline \multirow{4}{*}{$\cdot / \varphi^{\mu}=\mathrm{P}-$ value } & $V / q$ & 4 & $1 N / 0$ & 10 & r & \multirow{4}{*}{ تعداد فرزندان خانواده } \\
\hline & $\Delta \Delta / \mu$ & er & $\mathrm{Fr} /$. & mp & r & \\
\hline & $r \mu / V$ & 11 & 191 & 11 & $\Delta$ & \\
\hline & $1 \pi / r$ & 1. & $r \mu / \Delta$ & 19 & 4 & \\
\hline
\end{tabular}




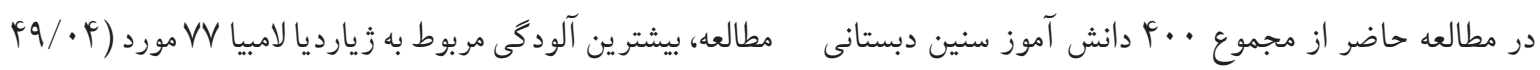

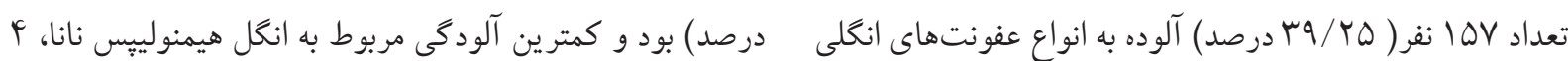

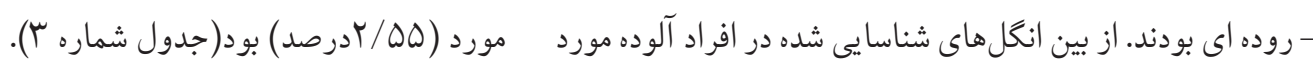
جدول سا. توزيع آلودَّيهاى انغَلى - روده اى در دانش آموزان بر حسب نوع انغَل

\begin{tabular}{|c|c|c|c|c|c|c|c|}
\hline \multicolumn{2}{|c|}{ 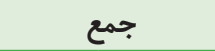 } & \multicolumn{2}{|c|}{ سالم } & \multicolumn{2}{|c|}{ آلوده } & \multirow{2}{*}{ آلود گى انگلى } & \multirow{2}{*}{ رديف } \\
\hline درصد & 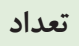 & درصد & تعداد & درصد & تعداد & & \\
\hline \multirow{6}{*}{$1 \cdots$} & \multirow{6}{*}{$r \ldots$} & \multirow{6}{*}{$G \cdot / V D$} & \multirow{6}{*}{ rF } & $p q / \cdot r$ & VV & 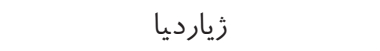 & 1 \\
\hline & & & & $r \cdot / \mu \wedge$ & rt & انتروبيوس ورميكولاريس(اكسيور) & r \\
\hline & & & & $r r / r q$ & ro & انتاموباكلى & r \\
\hline & & & & $r / \Delta \Delta$ & r & بلاستوسيستيس هومونيس & r \\
\hline & & & & $r / 19$ & $\Delta$ & لوداموبا بوتجلى & $\Delta$ \\
\hline & & & & $r / \Delta \Delta$ & r & هيمنوليِس نانا & 4 \\
\hline
\end{tabular}

1.. $\quad$ F..

جدول عا. مقايسه ميانكَين و انحراف معيار آلودگى انگلى در بين دانش آموزان مدارس ابتدايى در كَروه آزمون و كنترل قبل و بعد از مداخله

\begin{tabular}{|c|c|c|c|c|c|c|c|}
\hline \multirow{2}{*}{ P-value } & \multicolumn{2}{|c|}{ كروه آزمون } & \multicolumn{2}{|c|}{ كروه كنترل } & \multirow{2}{*}{ زمان } & \multirow{2}{*}{\multicolumn{2}{|c|}{ آلودگى انگلى }} \\
\hline & درصد & تعداد & درصد & تعداد & & & \\
\hline \multirow{4}{*}{$\begin{array}{l}\chi^{r}=r \mid / \Delta \\
P<\cdot / \cdots 1\end{array}$} & $81 / V$ & $\Delta$. & ro/o & $r V$ & قبل از مداخله & \multirow{2}{*}{ بيمار } & \multirow{4}{*}{ زيارديا } \\
\hline & N/s & $\checkmark$ & rN/q & rt & צ ماه بعد از مداخله & & \\
\hline & rN/r & r & $G F / F V$ & 4q & قبل از مداخله & \multirow{2}{*}{ سالم } & \\
\hline & $91 / 4$ & $V^{F}$ & VI/I & $\Delta F$ & צ ماه بعد از مداخله & & \\
\hline \multirow{4}{*}{$\begin{array}{l}\chi^{r}=\mid r / r \\
P<\cdot / \cdots \Delta\end{array}$} & $r Y / V$ & $r$. & $10 / 1$ & ir & قبل از مداخله & \multirow{2}{*}{ بيمار } & \multirow{4}{*}{ ورميكولاريس } \\
\hline & $r / \nu$ & r & $r r / F$ & IV & צ ماه بعد از مداخله & & \\
\hline & $V Q / \mu$ & 41 & $\lambda F / r \mid$ & $s F$ & قبل از مداخله & \multirow{2}{*}{ سالم } & \\
\hline & $9 s / \pi$ & v^ & $\mathrm{VV} / \mathrm{s}$ & $\Delta 9$ & ع ماه بعد از مداخله & & \\
\hline \multirow{4}{*}{$\begin{array}{l}\chi^{r}=1 r / 1 r \\
\mathrm{P}<\cdot / \cdots \Delta\end{array}$} & $r \vee /$. & r. & $\mu F / r l$ & rs & قبل از مداخله & \multirow{2}{*}{ بيمار } & \multirow{4}{*}{ انتاموباكلى } \\
\hline & $s / r$ & 0 & $\mathrm{rV} / \mathrm{s}$ & ri & و ماه بعد از مداخله & & \\
\hline & $\mu \varsigma /$. & 01 & $90 / \vee q$ & $\Delta$. & قبل از مداخله & \multirow{2}{*}{ سالم } & \\
\hline & $9 \pi / \wedge$ & Ve & $V Y / \mathcal{F}$ & $\Delta \Delta$ & ع ماه بعد از مداخله & & \\
\hline
\end{tabular}

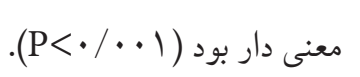

ابتلاى به انتروبيوس ورميكولاريس (اكسيور) قبل از درمان

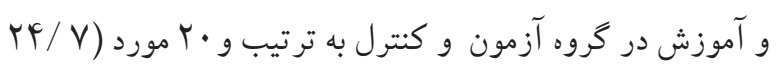

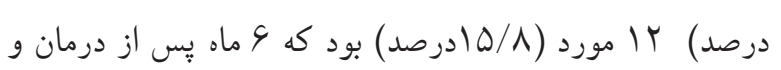

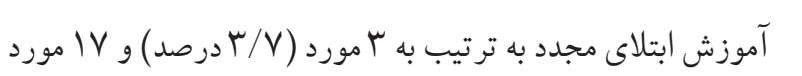

ابتلاى به زيارديا لامبيا قبل از درمان و آموزش در كروه آزمون

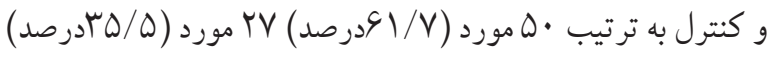

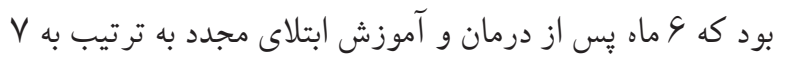

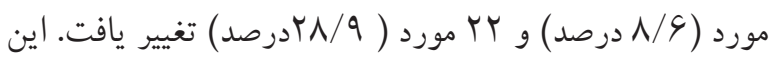
تغييرات در گروه آزمون نسبت به گروه كنترل از لحاظ آمارى 


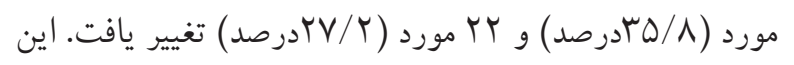

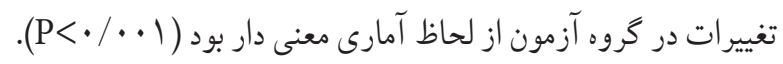
در كروه كنترل سطح آكاهى (كم، متوسط و بالا) دانش آموزان

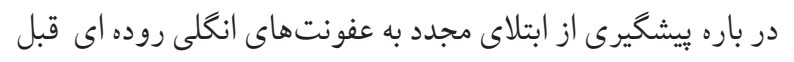

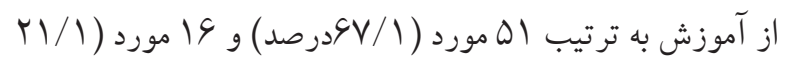

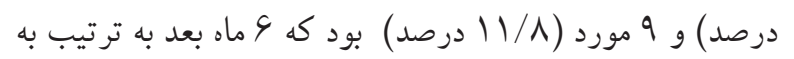

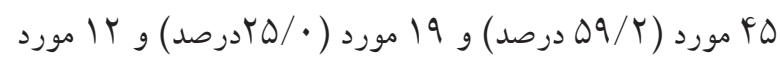

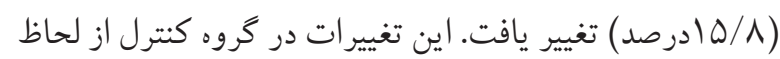

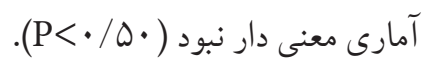

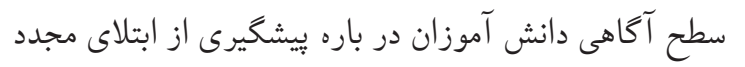

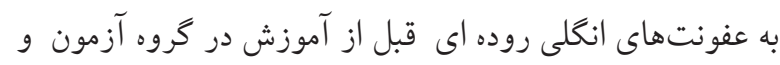

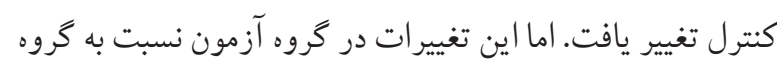

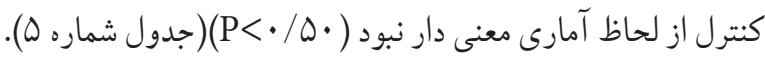

تغيير يافت. اين تغييرات در كروه آزمون نسبت به (T/F)

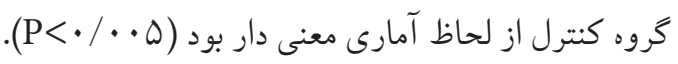

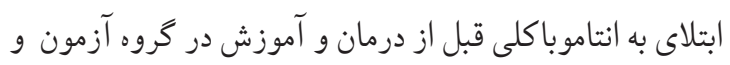

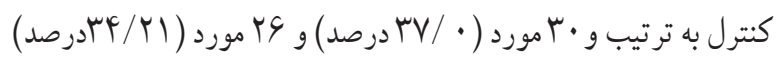

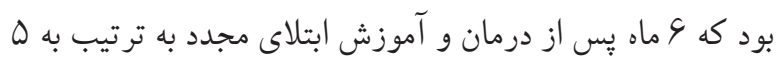

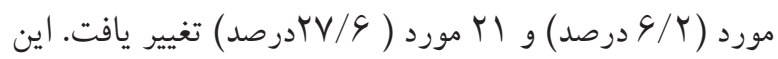

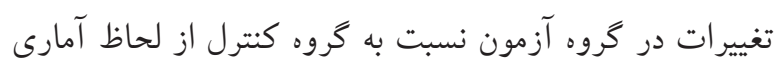

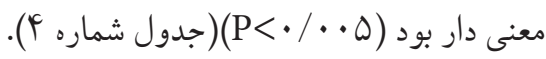

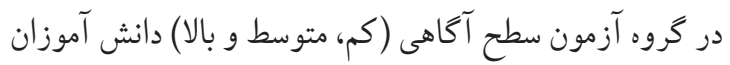

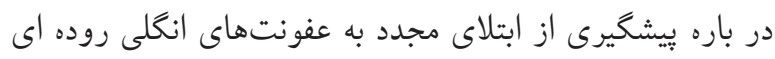

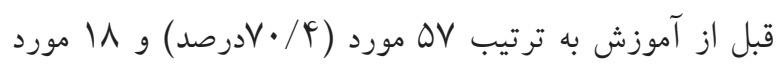
بود كه پِ از آموزش (

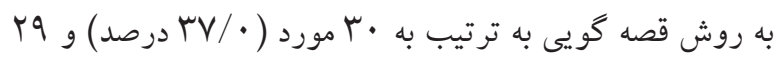

جدول ه. مقايسه فراوانى و درصد سطح اكَاهى دانش آموزان مدارس ابتدايى در باره آلودگى انتلى روده اى در كَروه آزمون و كنترل قبل و بعد از مداخله

\begin{tabular}{|c|c|c|c|c|c|c|c|c|c|}
\hline \multirow{3}{*}{ نتيجه آزمون } & \multicolumn{4}{|c|}{ كروه كنترل } & \multicolumn{4}{|c|}{ كروه آزمون } & \multirow{3}{*}{ سطح آكاهى } \\
\hline & \multicolumn{2}{|c|}{ ع ماه بعد از آموزش } & \multicolumn{2}{|c|}{ قبل از آموزش } & \multicolumn{2}{|c|}{ ع ماه بعد از آموزش } & \multicolumn{2}{|c|}{ قبل از آموزش } & \\
\hline & درصد & تعداد & درصد & تعداد & درصد & تعداد & درصد & تعداد & \\
\hline \multirow{4}{*}{$\begin{array}{c}c / 4 V=c r \\
\cdot / \Delta \cdot>P \\
G=d f\end{array}$} & $\Delta 9 / r$ & io & $s V / 1$ & 01 & $r \mathrm{~V} /$. & $r$. & $V \cdot / q$ & $\Delta V$ & كم \\
\hline & $r \Delta /$. & 19 & $r \mid / l$ & 19 & $r \Delta / \Lambda$ & rq & $r r / r$ & 11 & متوسط \\
\hline & $10 / \wedge$ & ir & $11 / 1$ & 9 & $r V / r$ & rr & $V / F$ & 4 & بالا \\
\hline & \multicolumn{2}{|c|}{$\chi^{r}=1 / .4$} & \multicolumn{2}{|c|}{$\mathrm{P}<\cdot / \Delta$} & \multicolumn{3}{|c|}{$\chi^{r}=r \cdot / 1$} & $\mathrm{P}<\cdot / . .1$ & نتيجه آزمون \\
\hline
\end{tabular}

بر اساس يافتههاى يزوهش، مداخله آموزشى باعث اتخاذ رفتارهاى اى جزء استراتزيهايى است كه در مطالعات مرتبط با آموزش بر آن تاكيد فراوان شده است.

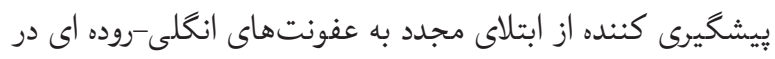
در مطالعه حاضر زمانى كه فراوانى و درصد سطح آكاهى دانش

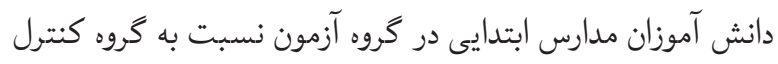

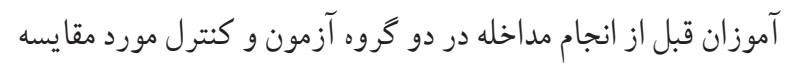

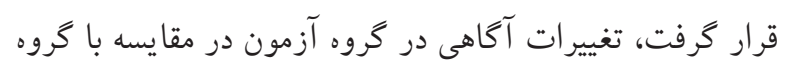

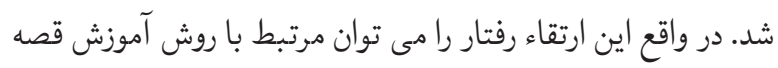

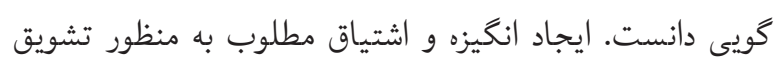

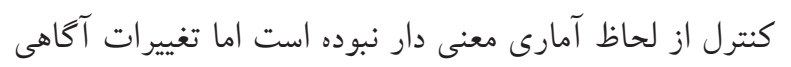
براى اتخاذ رفتارهاى ييشكيرى كننده از عفونت مجدد انكلى -روده 
روشن(1N) با عنوان" تأثير قصه گويى در كاهش يرخاشكرى بسران شش تا هشت ساله" كه در شهر شيراز انجام شد و همجنين

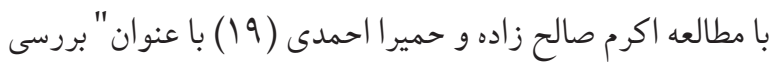
تاثير قصههاى آرام بخش بر يرخاشكرى كود كان" كه در شهر قم

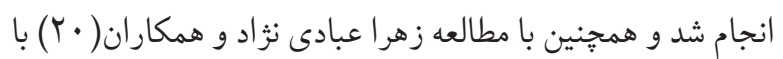

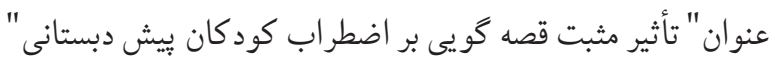
كه در شهر قائن انجام شد و همجنين با مطالعه رويا رسولى و

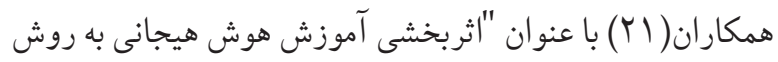

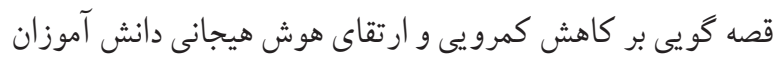
دختر" كه در شهر قم انجام شد، همسو بود د. همجنين نتايج حاصل از مطالعه حاضر مبنى بر اثربخشى امر مر مارد

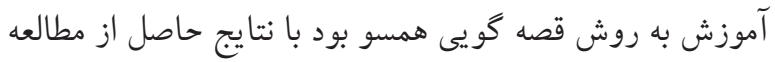

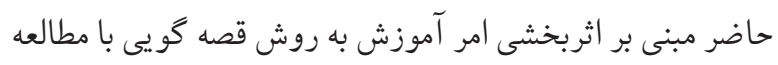

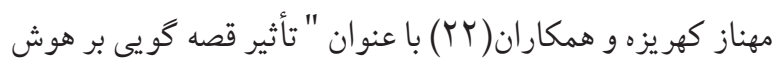

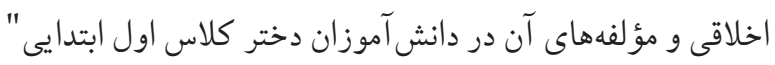

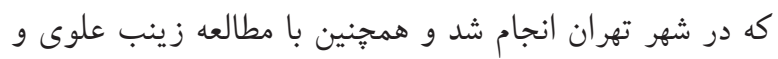

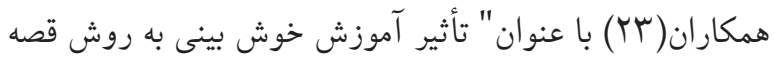

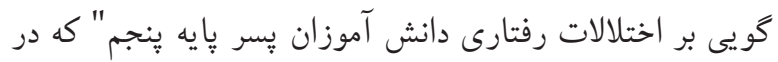

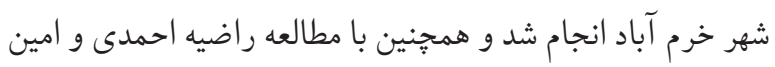

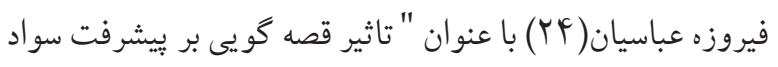

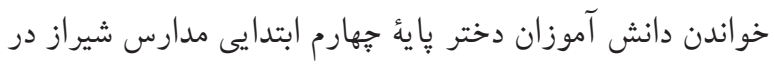
سال تحصيلى 9V-91" كه در شهر شيراز انجام شد.

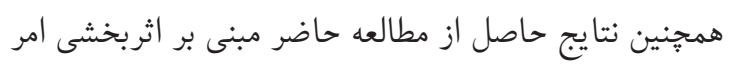

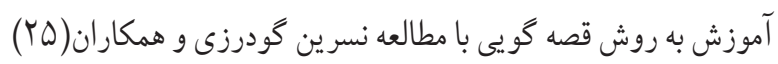

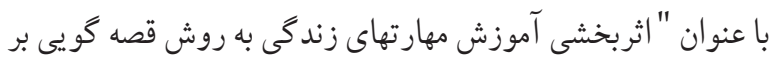

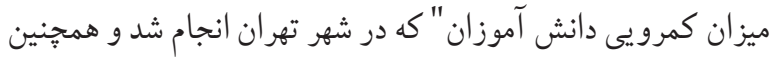

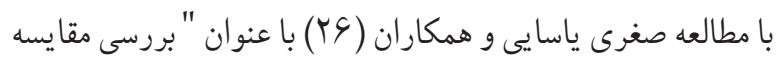

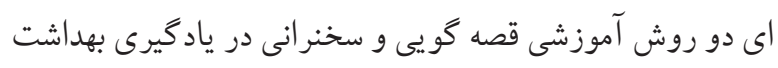

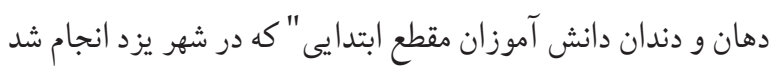

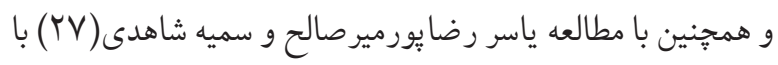
عنوان "اثربخشى آموزش هوش اخلاقى به شيوه قصه كويى بر بهبود
و اثرات قصه گويى در بيشگيرى از ابتلاى مجدد به آلودگىهاى

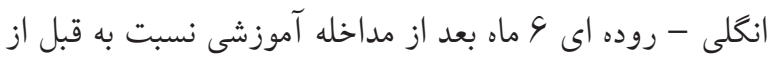

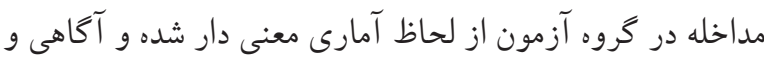
رفتار دانش آموزان در كروه آزمون ارتقاء يافته است. در صورتى كه آكاهى و رفتارهاى بيشكيرى كننده از عفونت

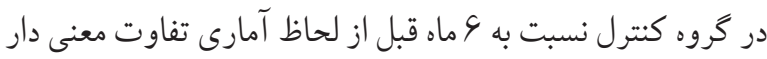
نداشته است (جدول شمارهم) كه اين امر ضرورت تداوم برنامههاى آموزشى و رفع مو انع در جهت تغيير و تثبيت رفتارهاى ييشخيرى

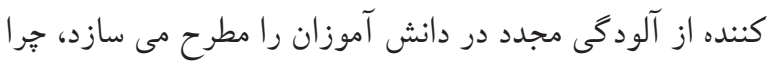

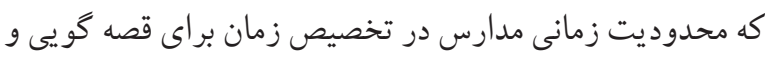

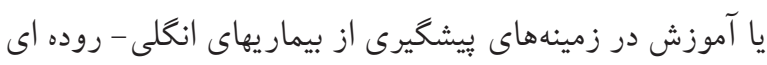

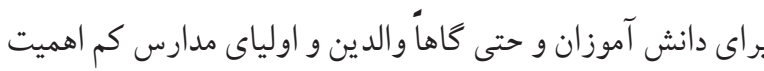
جلوه كر مى شود. عدم توجه به اين آلودگى ها در برنامه ريز يهاى آموزشى مدارس

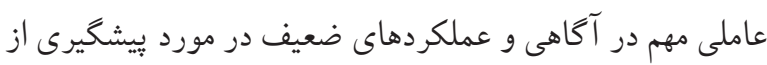

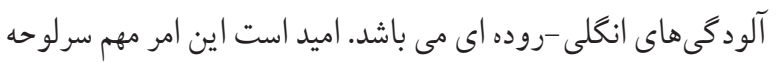

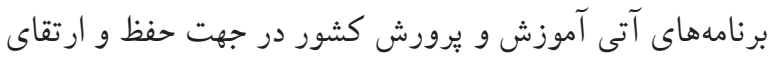

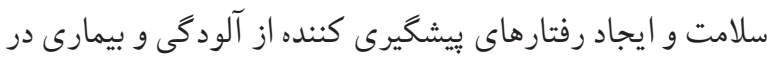
دانش آموزان قرار كيرد. نتايج حاصل از اثربخشى امر آموزش به روش قصه كويى درد

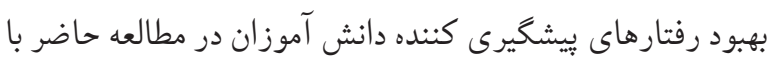

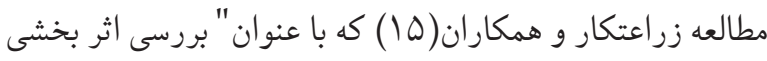

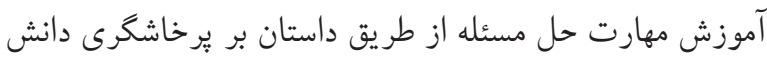

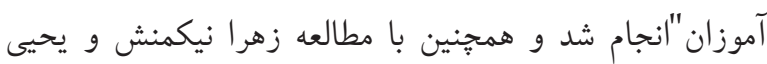

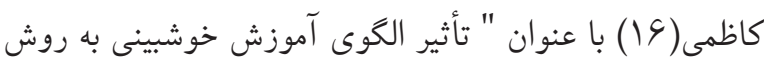

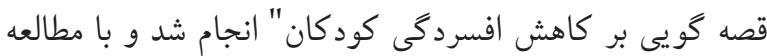

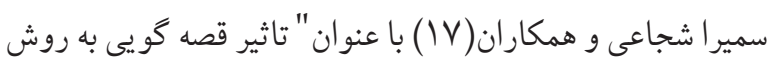
شناختى - رفتارى بر كاهش يرخاشگرى كود كان ييش دبستانى كه در شهر ايلام انجام شد، همسو بودئ

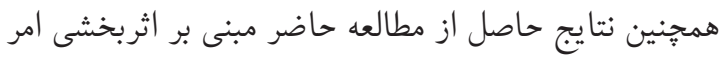

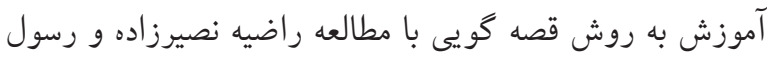




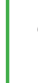

و ضرورت دارد سياست كذاران به اين امر توجه خاص داشته باشند. نتيجه گيرى بر اساس نتايج ، مى توان گفت كه روش قصه گويى در كاهش

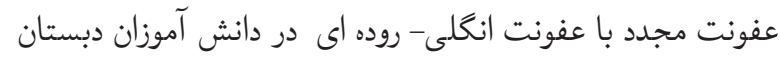

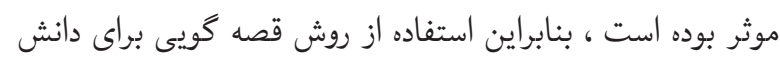

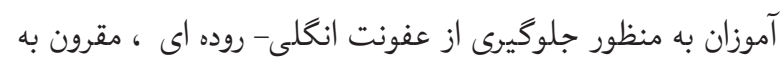

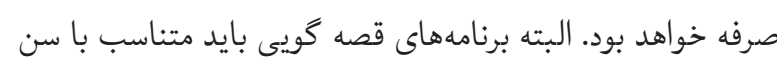

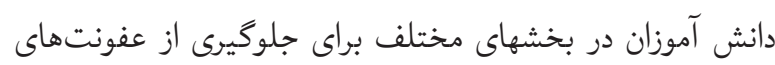

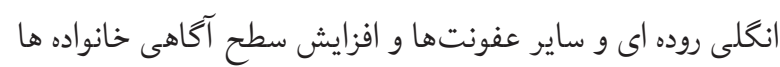
و همكارى آنها با دانش آموزان طراحى شود.

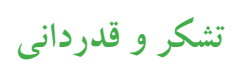

محققين از مرحوم استاد دكتر خسرو حضرتى تخه از گروه انكل

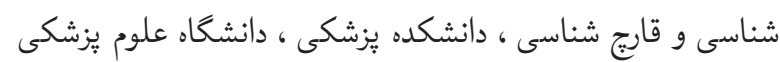

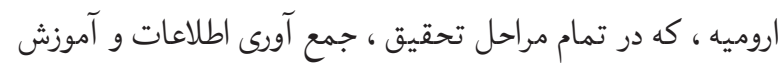

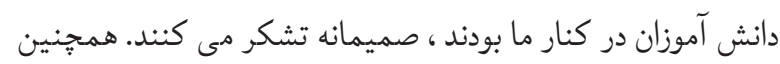

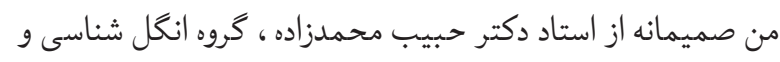

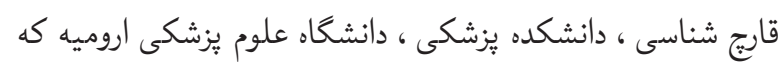

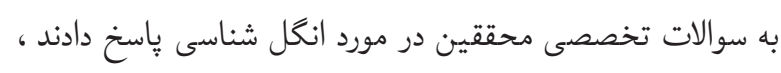
صميمانه تشكر مى كنيم.

12. Tehrani H, Olyani S. The Effect of an Education Intervention on Mental Health Literacy among Middle School Female Students. Journal of Health Literacy. 2021;5(4):41-7. https://doi.org/10.22038/jhl.2020.53492.1137
حالت هاى خُلقى و رفتارهاى يادگيرى دانش آموزان دختر دوره ابتدايى" كه در شهر ارد كان انجام شد و همجتنين با مطالعه ناهيد

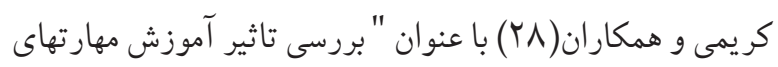

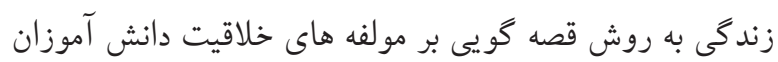

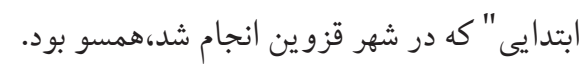

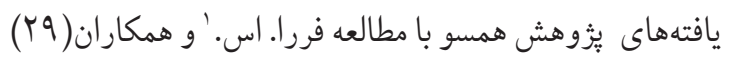

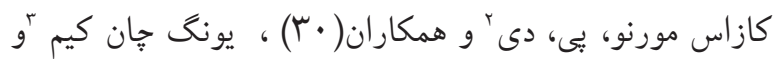

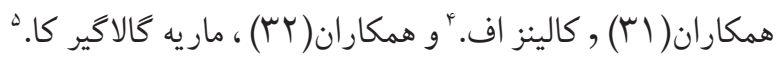

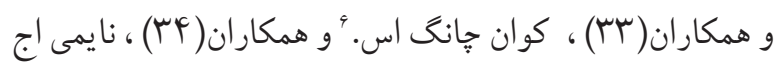

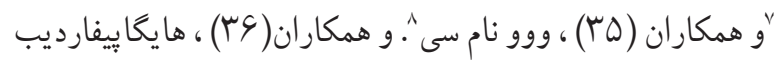

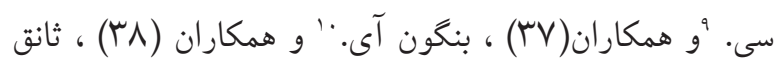

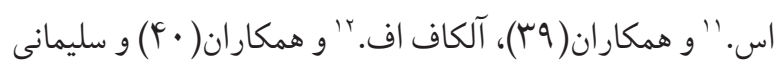

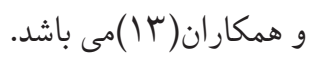
نتايج حاصل از اين مطالعه نشان مى دهد كه اجر اي برنامههاى

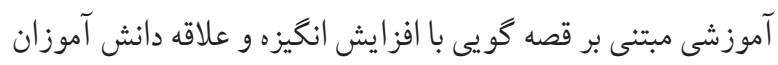

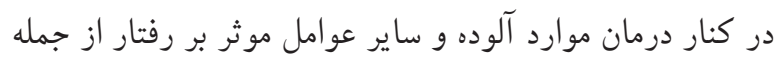

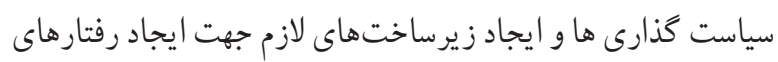

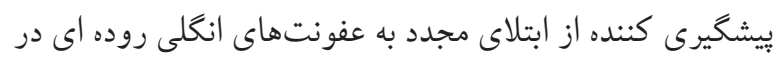

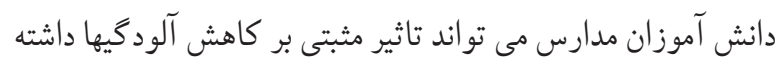

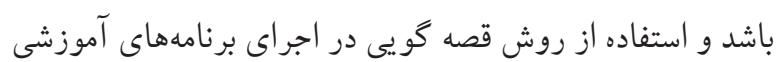
مى تواند نتايج مفيدى در بيى داشته باشد.

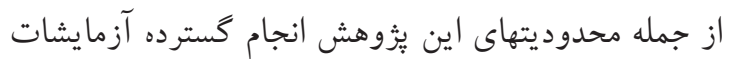

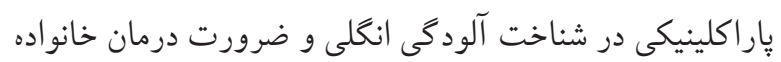

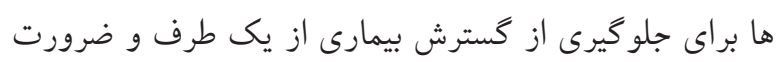

1. Ferreira S

2. Casas Moreno Pd

3. Yong-Chan Kim

4. Collins $F$

5. Marie Gallagher K

6. Kuan Chung $S$

7. Niemi $\mathrm{H}$

8. Woo Nam C

9. HaighaPipHardyb C

10. Bangun I, Li Z

11. Thang $S$

12. Alkaaf F 


\section{References}

1. Petersen S, Do T, Shaw C, BK. Developing a model of health behavior change to reduce parasitic disease in Vietnam. Health Education Research. 2016;31(6):716-28. h tt p s : / / d o i . org / 10.1093 / h e r / c y w 041 PMid:27744354

2. Beattie $R$, Brown $N$, Cass $H$. Millennium development goals progress report. Archives of disease in childhood. 2015;100(Suppl 1):S1-S. https://doi.org/10.1136/archdischild-2014-307933 PMid:25613958

3. Jejaw A, Zeynudin A, Zemene E, Belay T. Status of intestinal parasitic infections among residents of Jimma Town, Ethiopia. BMC Res Notes. 2014;7(502). https://doi.org/10.1186/1756-0500-7-502 PMid:25100301 PMCid:PMC4266909

4. Ksenia J. Zueva, Jaakko Lumme, Alexey E. Veselov, Matthew P. Kent, Sigbjørn Lien, R. C. Primmer Footprints of Directional Selection in Wild Atlantic Salmon Populations: Evidence for Parasite-Driven Evolution?. PLoS One. 2014;9(3). https://doi.org/10.1371/journal.pone.0091672 PMid:24670947 PMCid:PMC3966780

5. Eslami A. Veterinary Helminthology. Nematode and Acanthocephalan, University of Tehran;. 2006;3.

6. Edrisian GH, Rezaieyan M, Ghorbani M, Kashavarz H, M. M. Medical Protozoology. Mani Publishing. 2015;2.

7. Garcia LS. Diagnostic medical parasitology. Manual of commercialmethodsinclinicalmicrobiology.2001:274-305. https://doi.org/10.1128/9781555817961.ch11

8. Squier. SM. Parasites! Graphic Exploration of Tropical Disease Drug Development AMA Journal of Ethics. 2018;20(2):168.

h ttps: / / doi.org/10.1001/journal of e thics. 2018.20 .2 . m s oc $1-1802$ PMid:29460770

9. Abdi $\mathrm{H}$. The effect of individual health education in the prevention of infection with intestinal parasites in primary students in llam, . Journal of Medicine,. 2000;28.

10. S. E. Textbook of clinical parasitology protozoal disease in Iran. . 6th ed. Tehran: AEEIZH Publishing; 2015.

11. Margie Peden, Kayode Oyegbite, Joan Ozanne-Smith, Adnan A Hyder, Christine Branche, AKM Fazlur Rahman, et al. World report on child injury prevention. Switzerland: World Health Organization; 2008. Contract No.: ISBN 978 9241563574.

12. Tehrani $\mathrm{H}$, Olyani $\mathrm{S}$. The Effect of an Education Intervention on Mental Health Literacy among Middle School Female Students. Journal of Health Literacy. 2021;5(4):41-7. https://doi.org/10.22038/jhl.2020.53492.1137
13. Soleymani M, Hemmati S., Ashrafi-Rizi H., Shahrzadi L. Comparison of the effects of storytelling and creative drama methods on children's awareness about personal hygiene. J Educ Health Promot. 2017;6(82). https://doi.org/10.4103/jehp.jehp_56_16 PMid:29114550 PMCid:PMC5651658

14. Tohidi F, Mostafa Q. The Effect of Individual Health Education on Preventing School Students from Intestinal Parasitic Infection in Gorgan. . KNH. 2008;4((2)):14-7.

15. Zeraatkar H, M. M. The effect of problem-solving skills training based on storytelling on different levels of aggressive behaviors in students. JCMH. 2019;6((2)):68-80. https://doi.org/10.29252/jcmh.6.2.7

16. Nikmanesh Z, Kazemi Y. An examination of the effects of a model for teaching of optimism by storytelling on depression of children,. bjcp. 2010;5((1)):12-20.

17. Shojaei S, Bahrami H, H. S. The effect of methodologicalbehavioral storytelling on reducing aggression in preschool children in Ilam. . National Congress of Child and Adolescent Psychology; Shahid Beheshti University: Iranian Society of Clinical Psychology of Children and Adolescents; 2013.

18. Nasirzadeh R, Roshan R. The Effect of Storytelling on Aggression in Six to Eight-Year Old Boys. ijpcp. 2010;16((2)):118-26.

19. Salehzadeh A, Ahmadi H. Investigating the effect of soothing stories on children's aggression. . 8th ISPL Conferences; Zanjan: Zanjan University; 2013.

20. Ebadinejad Z, Barzegari Esfeden Z, Mirsaydi S. Effectiveness of storytelling in group discussion on anxiety of pre-school children. JPEN. 2019;5((3)).

21. Rasooli R MF, Hosseyniyaan S. Teaching through Storytelling as a Way of Improving Emotional Intelligence and Reducing Bashfulness among Female Students. QJOE. 2020;36((1) ):153-69.

22. Kahrizeh M, Rezaeian Faraji H, Zandipour T. The Effect of Storytelling on Moral Intelligence and its Components in Primary School Female Students J Child Ment Health. 2018;5( (2)):72-82.

23. Alavi Z, Ghadampour E, Ghazanfari F. The effect of teaching optimism by storytelling method on behavioral disorders of fifth grade male students Volume Number 2. . CPAP. 1396;15 ((2)):85-96.

24. Ahmadi R, Abbasian A. The effect of storytelling on the development of reading literacy of fourth grade elementary school students. ourmozd_literary. 1398;49:123-06.

25. Goodarzi N, Makond Hosseini S, Mohammadrezaei A, 
Akbari Balotbangan A. The effectiveness of life skills training using storytelling method on students' shyness,. jcps. 5((17)):136-21.

26. Yassaei S, Davari AR, Aghaei MR, Ghaffari Targhi M. Comparison Two Learning Methods of Oral Health EducationStorytelling and Speech on Elementary School Students in Yazd. . JOH Journal of Health. 2016;7((1)):1028.

27. Pourmirsaleh Yaser R, Shahedi S. The effectiveness of moral intelligence training through storytelling on improving moods and learning behaviors of female elementary school students

28. Karimi N, Mehrafzoon D, Jafari A. Investigating the effect of life skills training by storytelling method on the components of elementary students' creativity. . ICHS. 2017;7((2)):149-66.

29. Ferreira S, Alves AP, Quico C. How mobile can factor into a location based transmedia storytelling overall strategy: the TravelPlot Porto case study. Revista Turismo \& Desenvolvimento. 2014;2:141-9.

30. Casas Moreno Pd, Tejedor-Calvo S, Romero-Rodríguez LM. Micro-narratives on Instagram: analysis of the autobiographical storytelling and the projection of identities of the degrees in the field of communication. Prisma Social 2018;20:40-57.

31. Yong-Chan Kim , B. M, Moran HA. Integrated Connection to Neighborhood Storytelling Network, Education, and Chronic Disease Knowledge Among African Americans and Latinos in Los Angeles. Wilkin \&Sandra J. 2011:393-415 https://doi.org/10.1080/10810730.2010.546483 PMid:21302173

32. Collins F, The Use of Traditional Storytelling in Education to the Learning of Literacy Skills. Journal of Health Communication. 2011;16(4).

33. G. D, Solórzano, Tara J. Yosso. Critical Race Methodology: Counter-Storytelling as an Analytical Framework for
Education Research. Journal Theory Into Practice 2008;47(3).

34. Kuan Chung $S$, Art Education Technology: Digital Storytelling. Art Education. 2015;60(2). https://doi.org/10.1080/00043125.2007.11651632

35. Niemi $H$, Digital storytelling promoting twentyfirst century skills and student engagement. Technology, Pedagogy and Education. 2016;25( 4). https://doi.org/10.1080/1475939X.2015.1074610

36. Woo Nam C, The effects of digital storytelling on student achievement, social presence, and attitude in online collaborative learning environments. Interactive Learning Environments. 2017;25(3). https://doi.org/10.1080/10494820.2015.1135173

37. HaighaPipHardyb C, Tell me a story - a conceptual exploration of storytelling in healthcare education. Nurse Education Today. 2011;31( 4):408-11. https://doi.org/10.1016/j.nedt.2010.08.001 PMid:20810195

38. Bangun I, Li Z, Mannion P. Future Teacher Educators in Critical Evaluation of Educational Technology through Collaborative Digital Storytelling Projects. In: Graziano K, editor. Proceedings of Society for Information Technology\& Teacher Education International Conference; Las Vegas, NV, United States: Association for the Advancement of Computing in Education (AACE). 2020. p. 595-600.

39. Thang S, Mahmud N, Alfred Tng C. Digital Storytelling as an Innovative Approach to Enhance Learning Mandarin as a Second Language. Journal of e-Learning and Knowledge Society. 2020;11(2).

40. Alkaaf F, Perspectives of learners and teachers on implementing the storytelling strategy as a way to develop story writing skills among middle school students. JournalCogent Education. 2017;4(1). https://doi.org/10.1080/2331186X.2017.1348315 